\title{
Analisis Pengaruh Debt to Equity Ratio (DER), Return On Asset (ROA) dan Earning Per Share (EPS) terhadap Harga Saham melalui Kebijakan Dividen sebagai Variabel Intervening (Studi pada Perusahaan Manufaktur Sektor Industri Barang Konsumsi yang Terdaftar di Bursa Efek Indonesia 2015-2019)
}

\author{
Muhammad Zakaria \\ Program Studi Manajemen, Universitas Muria Kudus \\ Email korespondensi: zaka06468@gmail.com
}

Received: 8 Feb 2021 Reviewed: 19 Mar 2021 Accepted: 5 Apr 2021Published: 30 Apr 2021

\begin{abstract}
This study aims to determine the effect of debt to equity ratio, return on assets, and earnings per share on stock prices with dividend policy as an intervening variable. Secondary data is used in this quantitative study. Sample is gathered using purposive sampling technique. Data from 23 companies during 5 year are used as the sample. SEM AMOS is used in this study to analyse the data. This study found that return on assets, and earnings per share have significant and direct effect on stock prices and dividend policy. This study also revealed that the debt to equity ratio has no direct effect and significant on stock prices and dividend policy. Results of this study also indicated that the debt to equity ratio, return on assets, and earnings per share do not have indirect effects on stock prices with dividend policy as an intervening variable.
\end{abstract}

Keywords: debt to equity ratio, return on asset, earning per share, stock price, dividend policy

\begin{abstract}
ABSTRAK
Penelitian ini bertujuan untuk mengetahui pengaruh debt to equity ratio, return on asset, dan earning per share terhadap harga saham melalui kebijakan dividen sebagai variabel intervening. penelitian kuantitatif ini menggunakan data sekunder. Sampel dikumpulkan dengan purposive sampling. Didapatkan data dari 23 perusahaan selama 5 tahun yang digunakan dalam sampel penelitian. Analisis data dalam penelitian menggunakan analisis SEM AMOS. Penelitian ini memiliki hasil return on asset, dan earning per share berpengaruh secara langsung dan signifikan terhadap harga saham dan kebijakan dividen. Hasil pengujian juga mengungkapkan debt to equity ratio tidak berpengaruh secara langsung dan signifikan terhadap harga saham dan kebijakan dividen. Hasil penelitian ini juga menunjukkan bahwa debt to equity ratio, return on asset, dan earning per share tidak memiliki pengaruh tidak langsung terhadap harga saham melalui kebijakan dividen sebagai variabel intervening.
\end{abstract}

Kata kunci: debt to equity ratio, return on asset, earning per share, harga saham, kebijakan dividen

\section{A. PENDAHULUAN}

Harga saham merupakan sebuah cerminan dari nilai perusahaan. Di mana nilai perusahaan ini dapat didefinisikan sebagai tanggapan investor mengenai tingkat kesuksesan 
perusahaan dalam mengurus sumber dayanya. Apabila tingkat kepercayaan seorang calon investor maupun investor itu sendiri terhadap perusahaan tinggi, maka harga saham akan tinggi (Zuliarni, 2012). Begitupun sebaliknya, apabila tingkat kepercayaan calon investor atau investor itu sendiri terhadap perusahaan tersebut rendah, maka harga saham dimungkinkan akan rendah.

Investor menanamkan modal dalam perusahaan dengan tujuan utama untuk menerima pendapatan atau pengembalian investasi berupa capital gain dan dividend yield. Capital gain adalah selisih antara harga beli saham dengan harga jual saham, sedangkan dividend yield adalah laba perusahaan yang dialokasikan untuk pemegang saham (Hermuningsih, 2012). Dengan demikian, wajar apabila investor menghendaki return yang setinggi-tingginya pada investasi yang dilakukannya (Brigham \& Houston, 2010).

Selanjutnya, supaya keputusan investasi menjadi lebih matang, investor juga perlu memperhatikan sektor industri dimana perusahaan beroperasi sebagai dasar pengambilan keputusannya. Perusahaan manufaktur sektor industri barang konsumsi merupakan salah satu sektor perusahaan yang stabil dan tidak terlalu terpengaruh oleh kondisi perekonomian (Sari, 2017). Hal ini disebabkan karena produk perusahaan sektor industri barang konsumsi secara langsung dapat dirasakan oleh seluruh lapisan masyarakat, mulai dari kalangan bawah, kalangan menengah, hingga kalangan atas. Kondisi ini dibuktikan dengan kontribusi perusahaan sektor industri barang konsumsi mendorong perekonomian di Indonesia sebesar 56\% pada tahun 2017 (Aprilia, 2017).

Beberapa penelitian sebelumnya berusaha untuk mengungkapkan hubungan antara debt to equity ratio, return on asset, dan earning per share dengan harga saham. Penelitian Puspita (2017) yang mengungkapkan bahwa debt to equity ratio berpengaruh terhadap kebijakan dividen. Pernyataan tersebut sejalan dengan penelitian Darsono \& Ashari (2005) dan Oktadella (2011). Namun, bertentangan dengan penelitian yang dilakukan Suharli (2006), Deitiana (2009), Lisna \& Sudiartha (2011), Bangun \& Hardiman (2012) yang menyimpulkan bahwa debt to equity ratio tidak berpengaruh terhadap kebijakan dividen.

Penelitian yang dilakukan Kartikasari (2019) menyimpulkan bahwa debt to equity ratio berpengaruh secara signifikan terhadap harga saham. Penelitian tersebut sejalan dengan penelitian Dewi \& Suaryana (2013) dan Alifah \& Diyani (2017). Akan tetapi, hasil penelitian ini berbeda dengan penelitian yang dilakukan oleh Herawati \& Putra (2018) yang menyimpulkan bahwa debt equity ratio tidak berpengaruh terhadap harga saham.

Penelitian Cahyaningrum \& Antikasari (2017) menjelaskan jika return on asset berpengaruh secara signifikan terhadap harga saham. Pernyataan tersebut sejalan dengan 
penelitian Thim, Choong, \& Asri (2012), Haque, Datta, Dey, \& Rahman (2013), dan Muniarti (2016). Namun, hasil penelitian ini berlawanan dengan penelitian yang dilakukan oleh Sugiarto (2014) dan Satryo, Rokhmania, \& Diptyana (2016) yang menunjukkan bahwa return on asset tidak berpengaruh terhadap harga saham.

Penelitian Kartika, Topowijono, \& Endang (2015) jika return on asset berpengaruh secara signifikan terhadap kebijakan dividen. Pernyataan tersebut sejalan dengan penelitian Janifarus, Hidayat, \& Husaini (2013) dan Yudhanto (2013). Walaupun begitu, penelitian ini berbeda dengan Difah (2011) yang menyatakan return on asset tidak berpengaruh terhadap kebijakan dividen.

Penelitian Sitorus, Funny, Marcella, Evelyn, \& Gunawan (2020) memberitahukan bahwa earning per share berpengaruh secara signifikan terhadap harga saham. Pernyataan tersebut sejalan dengan penelitian Rahmawati \& Suryono (2017). Sementara itu, penelitian ini memiliki hasil yang berbeda dengan penelitian yang dilakukan Rahmadewi \& Abundanti (2018) yang menyimpulkan bahwa earning per share tidak berpengaruh terhadap harga saham.

Penelitian Dianti \& Badjra (2016) menyampaikan jika earning per share berpengaruh secara signifikan terhadap kebijakan dividen. Pernyataan tersebut sejalan dengan penelitian Yudhanto (2012), dan Siswantini (2014). Meskipun begitu, penelitian ini memiliki hasil yang berbeda dengan penelitian yang dilakukan Noviana (2012), Mehta (2012) menyimpulkan bahwa earning per share tidak berpengaruh terhadap kebijakan dividen.

Penelitian Sha (2015) memaparkan bahwa kebijakan dividen berpengaruh secara signifikan terhadap harga saham. Pernyataan tersebut sejalan dengan penelitian Clarensia \& Azizah (2013) dan Hutami (2012). Walaupun begitu, penelitian yang dilakukan Deitiana (2011) memiliki hasil yang berbeda dengan menyimpulkan bahwa kebijakan dividen tidak berpengaruh terhadap harga saham.

Hasil penelitian sebelumnya mengenai debt to equity ratio, return on asset, earning per share, dan kebijakan dividen dengan harga saham belum menunjukkan hasil yang sama. Hal ini masih menunjukkan bahwa masih terdapat research gap penelitian mengenai konsep tersebut. Berbagai penelitian terdahulu telah dipaparkan pada bagian latar belakang masalah, mulai dari hasil penelitian yang sejalan hingga hasil penelitian yang tidak sejalan. Berdasarkan uraian latar belakang yang telah dikemukakan, maka penelitian ini ingin menganalisis pengaruh debt to equity ratio, return on asset, dan earning per share terhadap harga saham melalui kebijakan dividen sebagai variabel intervening. 


\section{B. TELAAH PUSTAKA}

\section{Pengaruh Debt to Equity Ratio (DER) terhadap Kebijakan Dividen}

Debt to equity ratio adalah indikator untuk mengukur kemampuan operasi perusahaan yang stabil dan diukur dengan memperhitungkan kemampuan suatu perusahaan dalam membayar hutangnya. Oleh sebab itu, jika nilai debt to equity ratio meningkat maka dividen yang akan dibagikan kepada pemegang saham akan menurun, karena laba yang diperoleh perusahaan dipergunakan untuk membayar hutang. Sebaliknya, jika nilai debt to equity ratio semakin kecil, maka dividen yang akan dibagikan semakin besar, karena laba yang dipergunakan untuk membayar hutang perusahaan semakin kecil.

Puspita (2017) dalam penelitiannya berusaha untuk menguji hubungan likuiditas, profitabilitas, leverage dan market ratio terhadap kebijakan dividen. Penelitian yang menggunakan objek 13 perusahaan ini memiliki hasil jika leverage yang diukur menggunakan variabel debt to equity ratio berpengaruh terhadap kebijakan dividen. Hasil tersebut dapat dilihat pada bagian pengujian hipotesis pada tabel uji t, debt equity ratio memiliki signifikansi sebesar 0,000 yang artinya kurang dari 0,05 ini menandakan jika debt to equity ratio berpengaruh terhadap kebijakan dividen.

$\mathrm{H}_{1}$ : Debt to equity ratio berpengaruh secara langsung terhadap kebijakan dividen.

\section{Pengaruh Return On Asset (ROA) terhadap Kebijakan Dividen}

Penelitian Kartika, Topowijono, \& Endang (2015) menunjukkan bahwa ada pengaruh yang signifikan antara return on asset terhadap kebijakan dividen. Penelitian tersebut menguji hubungan return on asset, return on equity dan asset growth dengan harga saham. Dengan menggunakan data perusahaan sebanyak 141, penelitian ini mengatakan bahwa return on asset berpengaruh secara positif dan signifikan terhadap kebijakan dividen. Berdasarkan hasil tersebut, semakin meningkatnya nilai return on asset maka dividen yang akan dibagikan kepada pemegang saham juga meningkat. Begitupun sebaliknya, jika nilai return on asset suatu perusahaan mengalami penurunan, maka dividen yang akan dibagikan kepada pemegang saham juga akan menurun.

Gohar \& Alam (2018) mempelajari mengenai penentu dan perilaku kebijakan dividen pada perusahaan tercatat di Pakistan. Mereka menemukan bahwa ada hubungan antara profitabilitas perusahaan yang dihitung menggunakan return on asset terhadap kebijakan dividen. Penelitian ini pun menyimpulkan bahwa semakin besar keuntungan yang diterima sebuah perusahaan, maka semakin tinggi pula perusahaan akan membayar dividennya.

$\mathrm{H}_{2}$ : Return on asset berpengaruh secara langsung terhadap kebijakan dividen. 


\section{Pengaruh Earning Per Share (EPS) terhadap Kebijakan Dividen}

Berdasarkan penelitian Dianti \& Badjra (2016), menunjukkan bahwa terdapat pengaruh antara earning per share dan kebijakan dividen. Dengan menggunakan sampel perusahaan sebanyak 16 perusahaan, penelitian ini dilakukan guna menguji pengaruh earning per share, tingkat pertumbuhan, dan current ratio terhadap kebijakan dividen. Hasil penelitian tersebut diperoleh hasil dengan adanya pengaruh earning per share terhadap kebijakan dividen. Hal ini memperlihatkan jika earning per share yang mengalami kenaikan akan menjadikan perusahaan dapat membagikan dividen yang besar. Semakin meningkatnya nilai earning per share maka akan semakin tinggi pula dividen yang akan dibagikan kepada pemegang saham.

Penelitian sebelumnya yang dilakukan Masry, Sakr, \& Amer (2018) menggunakan 9 perusahaan perbankan yang terdaftar di ESE. Studi tersebut dilakukan untuk mempelajari faktor-faktor yang memengaruhi kebijakan dividen pada pasar modal baru di Yordania. Hasil penelitian menunjukkan bahwa earning per share memengaruhi kebijakan dividen.

$\mathrm{H}_{3}$ : Earning per share berpengaruh secara langsung terhadap kebijakan dividen.

\section{Pengaruh Debt to Equity Ratio (DER) terhadap Harga Saham}

Debt to equity ratio yang lebih tinggi akan memperlihatkan kinerja dari suatu perusahaan menjadi memburuk karena meningkatnya ketergantungannya perusahaan terhadap modal asing. Debt to equity ratio yang cukup besar dapat menyebabkan harga saham suatu perusahaan menurun. Hal ini disebabkan karena jika perusahaan menghasilkan sebuah keuntungan, maka keuntungan tersebut akan dipergunakan membayar hutang perusahaan daripada mengalokasikannya kepada pemegang saham (Suryawan \& Wirajaya, 2017).

Penelitian yang dilakukan oleh Kartikasari (2019) dilakukan untuk mengetahui pengaruh debt to equity ratio, current ratio, dan return on asset terhadap harga saham. Penelitian ini dilakukan pada 3 perusahaan go public dengan periode 10 tahun. Hasil penelitian tersebut mengatakan bahwa variabel debt to equity ratio berpengaruh terhadap harga saham. Hal ini dapat dibuktikan melalui uji t tabel yang memperlihatkan bahwa thitung variabel debt to equity ratio lebih besar daripada t tabelnya.

Ariyani, Andini, \& Santoso (2018) juga menemukan bahwa variabel debt to equity ratio berpengaruh secara tidak langsung terhadap harga saham melalui kebijakan dividen. Pengaruh tidak langsung antara debt to equity ratio terhadap harga saham melalui kebijakan dividen memiliki nilai yang lebih besar daripada nilai pengaruh langsungnya. Dapat disimpulkan bahwa kebijakan dividen memediasi pengaruh debt to equity ratio terhadap harga saham.

$\mathrm{H}_{4}$ : Debt to equity ratio berpengaruh secara langsung terhadap harga saham. 
$\mathrm{H}_{8}$ : Debt to equity ratio berpengaruh secara tidak langsung terhadap harga saham melalui kebijakan dividen sebagai variabel intervening.

\section{Pengaruh Return On Asset (ROA) terhadap Harga Saham}

Return on asset merupakan bentuk rasio profitabilitas yang mengukur kemampuan perusahaan untuk menghasilkan laba setelah menggunakan jumlah total aset yang ada dan menghilangkan biaya modal dari analisis. Manajemen sering menggunakan pengembalian aset sebagai alat ukur kinerja keuangan dan evaluasi kinerja operasional ketika menggunakan sumber daya yang tersedia (Hanum, 2009). Jika perusahaan memperoleh laba dari penggunaan semua sumber dayanya, nilai perusahaan yang diwakili oleh harga saham pun akan ikut naik.

Cahyaningrum \& Antikasari (2017) melakukan sebuah penelitian dengan tujuan untuk mencari hubungan earning per share, price to book value, return on asset, dan return on equity terhadap harga saham. Penelitian yang dilakukan selama 5 tahun periode pada 237 perusahaan sektor keuangan menunjukkan hasil bahwa variabel return on asset memiliki pengaruh terhadap harga saham. Bukti dari hasil penelitian tersebut adalah melalui tingkat signifikansi variabel return on asset sebesar 0,000 yang berarti lebih kecil daripada 0,05.

$\mathrm{H}_{5}$ : Return on asset berpengaruh secara langsung terhadap harga saham.

$\mathrm{H}_{9}$ : Return on asset berpengaruh secara tidak langsung terhadap harga saham melalui kebijakan dividen sebagai variabel intervening.

\section{Pengaruh Earning Per Share (EPS) terhadap Harga Saham}

Dewi \& Suaryana (2013) menyatakan earning per share menjelaskan keuntungan yang akan diperoleh seorang investor. Tingginya earning per share dicirikan oleh harga saham yang tinggi pula. Hal ini disebabkan karena earning per share bisa dipergunakan sebagai referensi bagi seorang investor dalam menganalisis saham terlebih dahulu sebelum melakukan investasi. Earning per share yang lebih tinggi akan meningkatkan harga saham perusahaan. Hal ini nantinya akan membuat investor tertarik menanamkan modal mereka, karena earning per share dapat memengaruhi besarnya keuntungan yang dibagikan oleh suatu perusahaan.

Penelitian terdahulu lainnya mengenai variabel earning per share terhadap harga saham adalah penelitian yang dilakukan oleh Devi \& T. (2015). Penelitian tersebut berusaha membuktikan adanya pengaruh price to book value, earning per share, dan debt to equity ratio terhadap harga saham dengan kebijakan dividen sebagai variabel intervening. Hasil penelitian ini mengungkapkan bahwa ada pengaruh tidak langsung antara earning per share dan harga saham melalui kebijakan dividen. Hal tersebut didasarkan pada nilai pengaruh tidak langsung yang memiliki nilai lebih tinggi dari pengaruh langsungnya.

$\mathrm{H}_{6}$ : Earning per share berpengaruh secara langsung terhadap harga saham. 
$\mathrm{H}_{10}$ : Earning per share berpengaruh secara tidak langsung terhadap harga saham melalui kebijakan dividen sebagai variabel intervening.

\section{Pengaruh Kebijakan Dividen terhadap Harga Saham}

Kebijakan dividen merupakan sebuah keputusan yang dibuat oleh perusahaan untuk menentukan berapa banyak laba yang dibagikan dalam bentuk dividen atau disimpan perusahaan sebagai laba ditahan. Kebijakan dividen adalah salah satu bagian dari keputusan investasi. Oleh karena itu, untuk mencapai hasil yang diharapkan oleh seorang investor, perusahaan diharuskan membagikan dividen.

Penelitian Sha (2015) dengan judul pengaruh kebijakan dividen, likuiditas, net profit margin, return on equity dan price to book value terhadap harga saham menunjukkan bahwa kebijakan dividen bernilai positif. Dapat dilihat pada tabel uji statistik yang menunjukkan jika kebijakan dividen memiliki nilai signifikansi 0,000 yang artinya kebijakan dividen memiliki pengaruh terhadap harga saham karena nilai signifikansi $<0,05$. Hal ini berarti perusahaan tersebut memiliki prospek baik di masa depan karena perusahaan dapat membagikan dividen dengan konstan kepada pemegang saham.

$\mathrm{H}_{7}$ : Kebijakan dividen berpengaruh secara langsung terhadap harga saham.

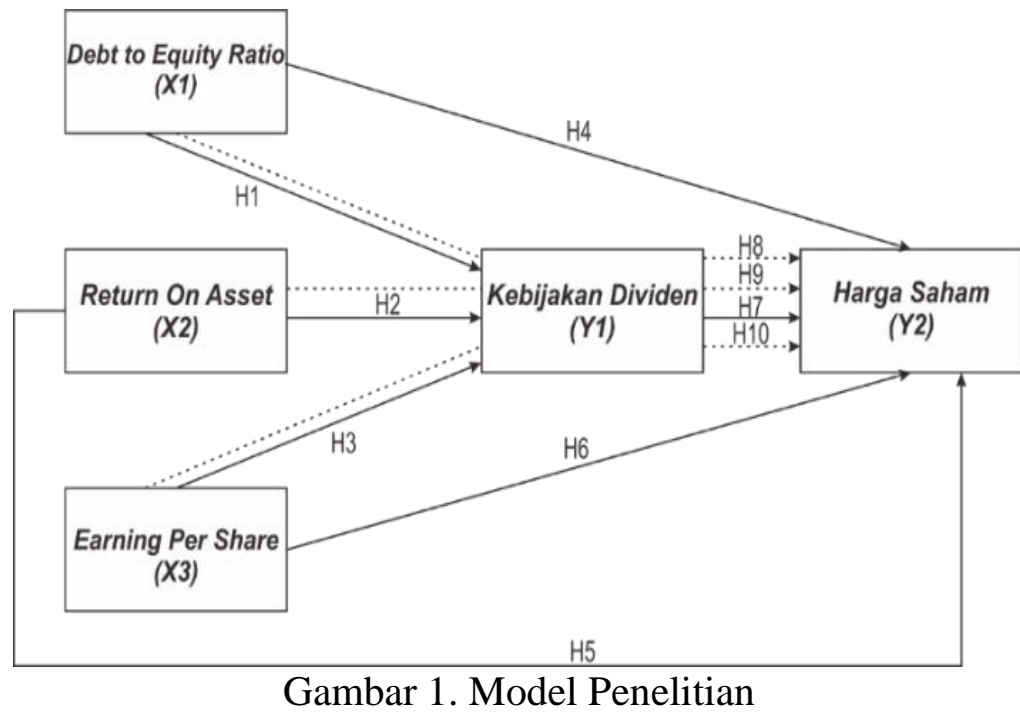

\section{METODE PENELITIAN}

\section{Objek Penelitian}

Penelitian ini mengambil objek penelitian perusahaan manufaktur sektor industri barang konsumsi yang terdaftar di Bursa Efek Indonesia pada tahun 2015-2019. Perusahaan manufaktur sektor industri barang konsumsi sendiri terdiri dari lima sub sektor yaitu sub sektor aneka makanan dan minuman, sub sektor rokok, sub sektor farmasi, sub sektor kosmetik, serta 
sub sektor keperluan rumah tangga. Perusahaan yang dipergunakan sebagai sampel dalam penelitian ini dipilih berdasarkan kriteria pemilihan sampel dengan teknik purposive sampling.

\section{Populasi dan Sampel}

Dalam penelitian ini, populasi yang digunakan adalah seluruh seluruh perusahaan manufaktur sektor industri barang konsumsi yang terdaftar di Bursa Efek Indonesia yang berjumlah 51 perusahaan. Sedangkan pada penelitian ini, penentuan sampel penelitian menggunakan non probability sampling. Non probability sampling merupakan teknik pengambilan sampel yang memberikan peluang berbeda untuk setiap elemen maupun anggota dari populasi yang nantinya digunakan sebagai sampel.

\section{Jenis dan Sumber Data}

Dalam penelitian ini, data yang dipergunakan merupakan data kuantitatif. Data kuantitatif merupakan sebuah data yang dapat dicari maupun dihitung secara langsung dalam bentuk informasi atau diinterpretasikan ke dalam bentuk angka. Umumnya, data kuantitatif akan menghasilkan hasil penjelasan berupa numeric dan akan diproses melalui metode statistik.

Sumber data yang dipergunakan pada penelitian ini merupakan secondary data (data sekunder). Secondary data merupakan sebuah data yang sudah ada seperti buku dan juga sebuah laporan, baik yang telah dipublikasikan dan tidak dipublikasikan secara umum (Sugiyono, 2010). Dalam penelitian ini, secondary data yang dipergunakan merupakan sebuah laporan keuangan dari perusahaan manufaktur sektor industri barang konsumsi yang terdaftar di Bursa Efek Indonesia pada periode 2015-2019. Secondary data tersebut dapat diperoleh melalui situs Bursa Efek Indonesia yaitu www.idx.co.id, maupun situs pada masing-masing perusahaan.

\section{Metode Analisis Data}

Ghozali (2017) menjelaskan bahwa tahap pemodelan serta persamaan struktural terbagi menjadi beberapa bagian yaitu :

1. Mengembangkan model berdasarkan teori

Persamaan struktural berdasarkan hubungan sebab akibat, yaitu dengan berubahnya satu variabel yang diperkirakan dapat berdampak pada berubahnya variabel lainnya. Kuatnya hubungan sebab akibat antara dua variabel yang diperkirakan oleh peneliti bukanlah dalam metode yang dipilih, melainkan landasan teori yang dipergunakan sebagai pendukung analisis.

2. Membuat persamaan struktural

Dalam penelitian ini, persamaan struktural yang dipergunakan adalah persamaan analisis jalur yaitu untuk mengetahui pengaruh langsung dan tidak langsung dari variabel yang 
digunakan dalam penelitian.

3. Memilih jenis input matrix dan estimasi model yang diusulkan

Pemodelan persamaan struktural berbeda dengan teknik analisis multivariat yang lain.

Data yang dipergunakan dalam structural equation model berbentuk matriks varian dan juga kovarian. Data pengamatan dapat dimasukkan ke dalam analysis of moment structure. Pertama program analysis of moment structure akan mengubah data mentah kedalam sebuah matriks korelasi.

4. Menilai identifikasi model struktural

Cara untuk memeriksa ada atau tidak adanya masalah dalam suatu identifikasi yaitu dengan melihat hasil estimasi yang mencakup nilai standard error yang tinggi antara satu koefisien dengan koefisien lain yakni (>0.90).

5. Mengidentifikasi Goodness-of-Fit

Goodness of fit dipergunakan sebagai ukuran penerapan input pada pengamatan aktual. Ghozali (2017) menerangkan bahwa goodness of fit dapat diukur menggunakan beberapa hal yaitu: $\mathrm{X}^{2}$-Chi-Square $<\mathrm{X}^{2} \alpha=0,05$; Significance Probability $\geq 0,05$; RMSEA bernilai antara 0,05 - 0,08; GFI $\geq 0,90 ; \mathrm{CMIN} / \mathrm{DF} \leq 2,00 ; \mathrm{AGFI} \geq 0,90 ; \mathrm{TLI} \geq 0,90 ; \mathrm{CFI} \geq 0,90$.

6. Analisis Koefisien Jalur

Analisis koefisien jalur dipergunakan untuk mengetahui pengaruh langsung maupun tidak langsung dalam penelitian. Dalam penelitian ini, sebuah variabel dapat dikatakan memiliki pengaruh langsung dan signifikan apabila nilai probabilitas dari koefisien jalur pengaruh langsung antar variabel adalah $<0,05$. Selain itu, dalam penelitian ini pula dapat dikatakan sebuah variabel dapat dikatakan memiliki pengaruh tidak langsung dan signifikan jika nilai koefisien jalur pengaruh tidak langsung lebih besar dari nilai pengaruh langsungnya dengan nilai probabilitas $<0,05$.

\section{HASIL DAN PEMBAHASAN}

\section{Uji Goodness Of Fit Index}

Melalui hasil pengujian yang telah dilakukan dapat diketahui jika penelitian ini memiliki hasil chi-square sebesar 0,000, dengan nilai probability 0,394, nilai RMSEA sebesar 0,454 serta nilai GFI 1,000. Berdasarkan hasil pengujian goodness of fit index diatas juga dapat diketahui pula nilai CMIN/DF sebesar 0,591, nilai AGFI sebesar 0,387, nilai TLI sebesar 1,00 dan juga nilai CFI sebesar 1,00. Dari hasil pengujian goodness of fit index yang telah dilakukan, maka dapat diartikan jika secara keseluruhan model penelitian ini dapat dikatakan baik. 
Tabel 1. Regression Weights

\begin{tabular}{llrrrrl}
\hline & & Estimate & S.E. & C.R. & P & Label \\
\hline DPR $<---$ & DER &, 033 &, 034 &, 969 &, 333 & par_1 \\
DPR $<---$ & ROA & 2,452 &, 554 & 4,427 & $* * *$ & par_3 \\
DPR $<---$ & EPS &, 390 &, 202 & 1,936 &, 043 & par_4 \\
SHM <--- & DER &,- 011 &, 009 & $-1,229$ &, 219 & par_2 \\
SHM <--- & ROA &, 432 &, 161 & 2,687 &, 007 & par_5 \\
SHM <--- & EPS &, 983 &, 055 & 17,106 &,$* * *$ & par_6 \\
SHM <--- & DPR &,- 013 &, 026 &,- 494 &, 621 & par_7 \\
\hline
\end{tabular}

Sumber: Hasil Pengolahan Amos, tahun 2020

\section{Uji Pengaruh Langsung dan Tidak Langsung}

Hasil pengujian yang telah dilakukan, terlihat dalam Tabel 1. Hasil penelitian menunjukkan pengaruh langsung debt to equity ratio (DER) terhadap kebijakan dividen (DPR) adalah sebesar 0,033 serta memiliki tingkat probabilitas sebesar 0,333. Oleh karena itu, dapat dikatakan jika tingkat probabilitas pengaruh langsung debt to equity ratio (DER) terhadap kebijakan dividen (DPR) lebih dari 0,05.

Melalui pengujian pengaruh langsung diketahui pula jika tingkat probabilitas pengaruh return on asset (ROA) terhadap kebijakan dividen (DPR) adalah 0,000 dengan nilai pengaruh langsung sebesar 2,452. Melalui pengujian pengaruh langsung bisa dilihat, bahwa pengaruh langsung return on asset (ROA) terhadap kebijakan dividen (DPR) memiliki nilai probabilitas yang lebih kecil dari 0,05.

Dari hasil pengujian yang telah dilakukan terlihat jika nilai pengaruh langsung earning per share (EPS) terhadap kebijakan dividen (DPR) adalah sebesar 0,390 dengan nilai probabilitas sebesar 0,043. Dengan kata lain tingkat probabilitas pengaruh langsung earning per share (EPS) terhadap kebijakan dividen (DPR) lebih kecil dari 0,05. Oleh karena itu, dapat disimpulkan dari hasil tersebut jika earning per share (EPS) berpengaruh secara langsung terhadap kebijakan dividen (DPR).

Berdasarkan pengolahan data regression weights tampak jika nilai probabilitas pengaruh langsung debt to equity ratio (DER) terhadap harga saham adalah 0,219. Selain itu diketahui pula nilai pengaruh langsung debt to equity ratio (DER) terhadap harga saham adalah sebesar $-0,011$. Hal tersebut dapat dikatakan nilai probabilitas pengaruh langsung debt to equity ratio (DER) terhadap harga saham lebih besar daripada 0,05. Oleh karena itu, dapat disimpulkan jika debt to equity ratio (DER) tidak berpengaruh secara langsung terhadap harga saham.

Hasil pengujian regression weights yang telah dilakukan juga menunjukkan probabilitas pengaruh return on asset (ROA) terhadap harga saham sebesar 0,007. Di sisi lain, hasil 
pengujian pengaruh langsung memperlihatkan jika nilai pengaruh langsung return on asset (ROA) terhadap harga saham adalah sebesar 0,432. Melalui hasil pengaruh langsung itu, dapat dikatakan jika return on asset (ROA) berpengaruh secara langsung terhadap harga saham. Hal tersebut didasarkan pada nilai probabilitas pengaruh langsung return on asset (ROA) terhadap harga saham yang lebih kecil dari 0,05.

Tabel 2. Hasil Pengujian Pengaruh Langsung \& Pengaruh Tidak Langsung

\begin{tabular}{lccccc}
\hline & & & Direct Effect & Indirect Effect & Total Effect \\
\hline DPR & $<---$ & DER & 0,033 & - & 0,033 \\
SHM & $<---$ & DER & $-0,011$ & 0,000 & $-0,11$ \\
DPR & $<---$ & ROA & 2,452 & - & 2,452 \\
SHM & $<---$ & ROA & 0,432 & $-0,031$ & 0,401 \\
DPR & $<---$ & EPS & 0,390 & - & 0,390 \\
SHM & $<---$ & EPS & 0,938 & $-0,005$ & 0,933 \\
SHM & $<---$ & DPR & $-0,013$ & - & $-0,013$ \\
\hline
\end{tabular}

Sumber: Hasil pengolahan AMOS, 2020

Pengolahan data pada Tabel 1 dapat dilihat jika pengaruh langsung earning per share (EPS) terhadap harga saham memiliki nilai probabilitas sebesar 0,000. Selanjutnya, dalam hasil pengujian pengaruh langsung juga diketahui pula nilai pengaruh langsung earning per share (EPS) terhadap harga saham sebesar 0,938. Berdasarkan hasil pengolahan data pada tabel pengaruh langsung maka dapat dikatakan bahwa earning per share (EPS) berpengaruh terhadap harga saham. Hal tersebut dikarenakan nilai probabilitas pengaruh langsung earning per share (EPS) terhadap harga saham yang lebih kecil dari 0,05.

\begin{tabular}{|c|c|c|c|c|}
\hline Input: & & Test statistic: & Std. Error: & p-value: \\
\hline a 0.033 & Sobel test: & -0.44448728 & 0.00096516 & 0.65669032 \\
\hline b -0.013 & Aroian test: & -0.32777863 & 0.00130881 & 0.74307905 \\
\hline$s_{a} 0.034$ & Goodman test: & -1.10740749 & 0.00038739 & 0.26811779 \\
\hline$s_{b} 0.026$ & Reset all & & Calculate & \\
\hline
\end{tabular}

Sumber: www.quantpsy.org, tahun 2020

Gambar 2. Hasil Uji Sobel Pengaruh Tidak Langsung DER Terhadap Harga Saham

Melalui uji sobel yang sudah dilakukan dapat diketahui pula nilai probabilitas pengaruh tidak langsung debt to equity ratio (DER) terhadap harga saham melalui kebijakan dividen (DPR) sebagai variabel intervening sebesar 0,66 . Berdasarkan hasil pengujian yang dapat dilihat pada Tabel 2, nilai pengaruh tidak langsung (direct effect) lebih besar daripada nilai pengaruh langsung (indirect effect) dengan probabilitas pengaruh tidak langsung yang diukur menggunakan uji sobel sebesar 0,66 (Gambar 2). Oleh karena itu, maka dapat disimpulkan jika 
debt to equity ratio (DER) tidak memiliki pengaruh secara tidak langsung terhadap harga saham melalui kebijakan dividen (DPR).

\begin{tabular}{|c|c|c|c|}
\hline Input: & Test statistic: & Std. Error: & $p$-value: \\
\hline a 2.452 & Sobel test: -0.49683972 & 0.06415751 & 0.61930208 \\
\hline$b-0.013$ & Aroian test: -0.4847725 & 0.06575456 & 0.62783773 \\
\hline$s_{a} 0.554$ & Goodman test: -0.50985541 & 0.06251969 & 0.61015276 \\
\hline$s_{b} 0.026$ & Reset all & Calculate & \\
\hline
\end{tabular}

Sumber: www.quantpsy.org, tahun 2020

Gambar 3. Hasil Uji Sobel Pengaruh Tidak Langsung ROA Terhadap Harga Saham

Pengujian yang dilakukan dengan menggunakan uji sobel memperlihatkan jika nilai probabilitas pengaruh tidak langsung (indirect effect) return on asset (ROA) terhadap harga saham melalui kebijakan dividen (DPR) memiliki nilai yang tinggi yakni 0,62 (Gambar 3). Berdasarkan hasil uji sobel dan juga pengujian pengaruh tidak langsung (indirect effect) yang telah dilakukan, maka dapat ditarik kesimpulan jika kebijakan dividen (DPR) tidak memediasi pengaruh return on asset (ROA) terhadap harga saham dengan signifikan. Hal tersebut didasarkan pada nilai pengaruh tidak langsung (indirect effect) yang lebih kecil dari nilai pengaruh langsung (direct effect). Selain itu juga didasarkan pada nilai probabilitas pengaruh tidak langsung (indirect effect) yang lebih tinggi dari 0,05 .

\begin{tabular}{|c|c|c|c|c|}
\hline Input: & & Test statistic: & Std. Error: & p-value: \\
\hline a 0.390 & Sobel test: & -0.48403193 & 0.01047452 & 0.62836321 \\
\hline b -0.013 & Aroian test: & -0.43268746 & 0.01171746 & 0.66524184 \\
\hline$s_{a} 0.202$ & Goodman test: & -0.55943783 & 0.00906267 & 0.57586295 \\
\hline Sb 0.026 & Reset all & & Calculate & \\
\hline
\end{tabular}

Sumber: www.quantpsy.org, tahun 2020

Gambar 4. Uji Sobel Pengaruh Tidak Langsung EPS Terhadap Harga Saham

Hasil pengujian terakhir pengaruh tidak langsung (indirect effect) earning per share (EPS) terhadap harga saham memperoleh hasil akhir sebesar -0,005. Melalui pengujian sobel test yang telah dilakukan pada Gambar 4 terlihat jika nilai pengaruh tidak langsung earning per share memiliki nilai probabilitas sebesar 0,63. Berdasarkan hasil pengujian tersebut maka nilai probabilitas yang dihasilkan lebih besar dari 0,05 dengan nilai pengaruh tidak langsung (indirect effect) yang lebih kecil dari nilai pengaruh langsung (direct effect). Oleh sebab itu, maka dapat disimpulkan jika earning per share (EPS) tidak berpengaruh secara tidak langsung dan signifikan terhadap harga saham. 


\section{Pembahasan}

\section{Pengaruh Langsung Debt to Equity Ratio (DER) terhadap Kebijakan Dividen (DPR)}

Pada hasil pengujian yang sudah dilakukan, dapat dikatakan jika debt to equity ratio (DER) tidak berpengaruh secara langsung terhadap kebijakan dividen. Hasil pengujian ini membuktikan bahwa tinggi dan juga rendahnya nilai debt to equity ratio (DER) tidak memengaruhi pembayaran dividen yang nantinya akan diterima oleh para pemegang saham perusahaan. Hal tersebut bisa terjadi sebab kewajiban perusahaan untuk membayar seluruh hutangnya bukan diambil dari laba yang diterima oleh perusahaan, tetapi diambil dari modal para pemegang saham perusahaan (Bangun \& Hardiman, 2012).

Hasil penelitian ini mendukung beberapa penelitian terdahulu yang dilakukan oleh Suharli (2006), Deitiana T. (2009), Lisna \& Sudiartha (2011), Bangun \& Hardiman (2012). Namun, hasil penelitian ini bertentangan dengan hasil penelitian yang dilakukan oleh Darsono \& Ashari (2005), serta Oktadella (2011) yang menyimpulkan bahwa debt to equity ratio (DER) berpengaruh terhadap kebijakan dividen (DPR).

\section{Pengaruh Langsung Return On Asset (ROA) terhadap Kebijakan Dividen (DPR)}

Berdasarkan hasil pengujian yang telah dilakukan maka dapat dikatakan jika return on asset berpengaruh secara langsung terhadap kebijakan dividen. Dengan hasil pengujian pengaruh langsung (direct effect) yang telah dilakukan pula dapat dikatakan bahwa perusahaan yang dipergunakan sebagai objek dalam penelitian mampu mengelola semua aset yang dimilikinya secara efektif untuk menghasilkan laba dari aset yang dimiliki. Hal tersebut sama dengan yang diungkapkan oleh Brigham \& Houston (2010), bahwa semakin positif nilai return on asset (ROA) maka pengelolaan perusahaan lebih efisien yang nantinya akan menjadikan perusahaan menghasilkan laba yang lebih tinggi. Semakin tinggi nilai return on asset maka akan semakin tinggi pula kemampuan perusahaan untuk membayarkan dividen kepada para pemegang saham perusahaan.

Hasil penelitian ini sejalan dengan penelitian Janifairus, Hidayat, \& Husaini (2013), dan Yudhanto (2013). Akan tetapi hasil penelitian ini berbeda dengan hasil penelitian yang dilakukan oleh Difah (2011) yang menyatakan return on asset (ROA) tidak berpengaruh terhadap kebijakan dividen (DPR).

\section{Pengaruh Langsung Earning Per Share (EPS) terhadap Kebijakan Dividen (DPR)}

Melalui hasil pengujian yang telah dilakukan untuk mengetahui pengaruh langsung earning per share (EPS) terhadap kebijakan dividen (DPR) memiliki hasil jika earning per share (EPS) berpengaruh secara langsung dan signifikan terhadap kebijakan dividen (DPR). Berdasarkan hasil tersebut, dapat dikatakan semakin meningkat atau menurunnya nilai earning 
per share (EPS) akan memengaruhi dividen yang akan dibagikan kepada para pemegang saham.

Darmadji \& Fakhruddin (2012) menjelaskan bahwa earning per share (EPS) memperlihatkan rasio bagi hasil dari setiap saham yang dimiliki. Jika semakin besar nilai earning per share (EPS) tentu akan semakin menyenangkan bagi para pemegang saham. Hal tersebut dikarenakan meningkatnya earning per share (EPS) akan menjadikan perusahaan dapat membagikan dividen yang lebih besar kepada para pemegang saham perusahaan.

Hasil penelitian ini sejalan dengan penelitian yang dilakukan oleh Dianti \& Badjra (2016), Yudhanto (2012), dan Siswantini (2014). Meskipun begitu, penelitian ini memiliki hasil yang berbeda dengan penelitian yang dilakukan oleh Noviana (2012), Mehta (2012) yang menyimpulkan bahwa earning per share (EPS) tidak berpengaruh terhadap kebijakan dividen (DPR).

\section{Pengaruh Langsung Debt to Equity Ratio (DER) terhadap Harga Saham}

Berdasarkan hasil pengujian yang telah dilakukan diketahui jika debt to equity ratio (DER) tidak berpengaruh terhadap harga saham. Berdasarkan hasil pengujian tersebut pula dapat dikatakan, tinggi rendahnya nilai debt to equity ratio (DER) tidak memengaruhi naik turunnya harga saham. Hasil pengujian tersebut juga dapat dikatakan jika tinggi rendahnya nilai debt to equity ratio (DER) tidak memengaruhi seorang investor dalam membeli sebuah saham.

Hasil penelitian ini mendukung penelitian yang dilakukan oleh Herawati \& Putra (2018) yang mengungkapkan jika debt to equity ratio (DER) tidak berpengaruh terhadap harga saham. Akan tetapi hasil penelitian ini juga berbeda dengan penelitian yang dilakukan oleh Kartikasari (2019), Dewi \& Suaryana (2013), dan juga Alifah \& Diyani (2017) yang menyimpulkan jika debt to equity ratio (DER) berpengaruh terhadap harga saham.

\section{Pengaruh Langsung Return On Asset (ROA) terhadap Harga Saham}

Berdasarkan hasil pengujian yang telah dilakukan maka dapat dikatakan jika return on asset (ROA) mengalami kenaikan maka harga saham juga akan naik. Begitupun sebaliknya, apabila return on asset (ROA) mengalami penurunan maka harga saham juga akan menurun. Semakin tinggi nilai return on asset (ROA) maka perusahaan akan menghasilkan laba yang lebih besar pula dari aset yang dimilikinya. Semakin besar laba yang diperoleh perusahaan dari aset yang dimilikinya akan menjadikan investor lebih tertarik untuk membeli saham perusahaan yang nantinya akan menjadikan nilai perusahaan semakin tinggi. Apabila nilai perusahaan semakin tinggi maka harga saham juga akan cenderung meningkat. 
Penelitian ini sejalan dengan penelitian yang dilakukan oleh Cahyaningrum \& Antikasari (2017), Thim, Chong, \& Asri (2012), Haque, Datta, Dey, \& Rahman (2013), dan Muniarti (2016) yang mengungkapkan jika return on asset (ROA) berpengaruh positif terhadap harga saham. Namun, hasil penelitian ini berbeda dengan hasil penelitian yang dilakukan oleh Sugiarto (2014) dan Satryo, Rokhmania, \& Diptyana (2016) yang menunjukkan bahwa return on asset tidak berpengaruh terhadap harga saham.

\section{Pengaruh Langsung Earning Per Share (EPS) terhadap Harga Saham}

Melalui hasil pengujian yang sudah dilakukan, earning per share (EPS) berpengaruh secara langsung dan signifikan terhadap harga saham. Hasil tersebut dapat dikatakan jika naik turunnya nilai earning per share (EPS) akan memengaruhi harga saham. Selain itu, pengujian tersebut juga sekaligus menerima hipotesis keenam yang mengatakan jika earning per share (EPS) berpengaruh secara langsung terhadap harga saham.

Earning Per Share (EPS) memperlihatkan kemampuan perusahaan dalam memperoleh laba bersih dari setiap lembar saham. Apabila nilai earning per share (EPS) semakin meningkat hal tersebut akan semakin baik dikarenakan dapat menaikkan harga saham yang tentunya akan menguntungkan bagi perusahaan. Sebuah perusahaan yang memiliki nilai earning per share (EPS) yang tinggi tentu akan menjadikan investor lebih tertarik (Jogiyanto, 2012). Hal tersebut dikarenakan earning per share (EPS) menandakan jika meskipun harga saham mengalami kenaikan, akan tetapi keuntungan yang diterima investor juga akan meningkat.

Pernyataan penelitian ini sejalan dengan hasil penelitian yang dilakukan oleh Sitorus, Funny, Marcella, Evelyn, \& Gunawan (2020), Rahmawati \& Suryono (2017). Sementara itu, hasil penelitian ini juga berbeda dengan hasil penelitian yang dilakukan oleh Rahmadewi \& Abundanti (2018) yang menyimpulkan bahwa earning per share tidak berpengaruh terhadap harga saham.

\section{Pengaruh Langsung Kebijakan Dividen (DPR) terhadap Harga Saham}

Berdasarkan hasil pengujian yang telah dilakukan, diperoleh hasil bahwa kebijakan dividen berpengaruh secara langsung terhadap harga saham. Hasil penelitian ini menolak hipotesis ketujuh yang mengungkapkan jika kebijakan dividen berpengaruh terhadap harga saham. Melalui hasil tersebut secara langsung dapat dikatakan jika dividen yang dibagikan tidak menjadi salah satu hal yang diperhatikan para investor dalam melakukan investasi.

Berdasarkan hasil pengujian dapat dikatakan jika jumlah pembagian dividen terhadap para pemegang saham tidak memengaruhi naik dan juga turunnya harga saham. Hal tersebut dikarenakan seorang investor dalam melakukan sebuah investasi cenderung hanya memperhatikan laba yang dihasilkan perusahaan dan berapa laba jangka pendek (capital gain) 
yang diterima oleh investor jika melakukan sebuah investasi (Aprillianto, Wulandari, \& Kurrohman, 2014). Hasil penelitian ini sejalan dengan hasil penelitian yang dilakukan oleh Sha (2015), Clarensia \& Azizah (2013), dan Hutami (2012). Walaupun begitu hasil penelitian ini berbeda dengan hasil penelitian yang dilakukan oleh Deitiana (2011).

\section{Pengaruh Tidak Langsung Debt to Equity Ratio (DER) terhadap Harga Saham melalui Kebijakan Dividen (DPR)}

Berdasarkan hasil yang telah diperoleh, dapat dikatakan bahwa hipotesis kedelapan yang mengatakan jika debt to equity ratio (DER) berpengaruh terhadap harga saham melalui kebijakan dividen melalui kebijakan dividen (DPR) sebagai variabel intervening dapat ditolak. Berdasarkan hasil pengujian yang telah dilakukan, bisa diartikan meningkatnya hutang perusahaan yang diukur menggunakan debt to equity ratio tidak menjadi sebuah tolok ukur untuk menjadikan harga saham meningkat pula. Selain itu pula dapat dikatakan bahwa meningkatnya harga saham tidak melihat nilai debt to equity ratio dengan melalui kebijakan dividen. Hal tersebut dikarenakan meningkatnya nilai debt to equity ratio tidak dapat menjadikan dividen yang diterima para pemegang saham juga akan meningkat.

Meningkatnya nilai debt to equity ratio justru akan menjadikan laba yang diperoleh perusahaan akan dialokasikan untuk membayar hutangnya (Bangun \& Hardiman, 2012). Hasil penelitian ini sejalan dengan penelitian yang dilakukan oleh Bulutoding, Parmitasari, \& Dahlan (2018) yang mengungkapkan jika debt to equity ratio (DER) tidak memiliki pengaruh secara tidak langsung terhadap harga saham melalui kebijakan dividen (DPR) sebagai variabel intervening.

\section{Pengaruh Tidak Langsung Return On Asset (ROA) terhadap Harga Saham melalui Kebijakan Dividen (DPR)}

Berdasarkan hasil pengujian tersebut dapat dikatakan jika nilai pengaruh tidak langsung (indirect effect) return on asset (ROA) terhadap harga saham melalui kebijakan dividen (DPR) lebih kecil daripada nilai pengaruh langsungnya. Selain itu, melalui uji sobel juga diketahui jika return on asset (ROA) memiliki pengaruh yang tidak signifikan terhadap harga saham melalui kebijakan dividen. Melalui hasil pengujian yang telah dilakukan tersebut pula, dapat dikatakan jika return on asset tidak menjadi sebuah acuan untuk seorang investor dalam melihat potensi investasi yang dilakukan. Hal tersebut dikarenakan laba yang diperoleh perusahaan dari aset yang dimiliki tidak semua dialokasikan ke dalam bentuk dividen untuk dibagikan kepada para pemegang saham perusahaan (Arif, 2019). 
Pengaruh Tidak Langsung Earning Per Share (EPS) terhadap Harga Saham melalui Kebijakan Dividen (DPR)

Berdasarkan hasil pengujian didapatkan bahwa nilai pengaruh tidak langsung (indirect effect) earning per share terhadap harga saham melalui kebijakan dividen lebih kecil dari pengaruh langsung (direct effect). Selain itu, hasil pengujian sobel test yang dilakukan juga menunjukkan bahwa kebijakan dividen tidak dapat memediasi pengaruh earning per share (EPS) terhadap harga saham. Berdasarkan hasil pengujian tersebut, maka dapat diartikan semakin tinggi laba per lembar saham yang nantinya diperoleh oleh para pemegang saham tidak dapat menjadikan harga saham menjadi meningkat melalui tingkat pembayaran dividen yang dilakukan perusahaan.

Hasil penelitian ini sependapat dengan penelitian yang dilakukan Lestari \& Susetyo (2020) yang menyimpulkan jika kebijakan dividen (DPR) tidak dapat menjadi variabel mediasi pengaruh earning per share (EPS) terhadap harga saham. Selain itu, literatur yang mendukung hasil penelitian ini dikemukakan oleh Noviana (2012) yang menjelaskan tingginya nilai earning per share belum tentu menjadikan perusahaan membayarkan dividen yang tinggi pula kepada para pemegang saham perusahaan.

\section{E. KESIMPULAN}

Berdasarkan hasil pengujian yang telah dilakukan maka dapat dikatakan jika debt to equity ratio tidak memiliki pengaruh secara langsung terhadap kebijakan dividen. Hal tersebut dapat dikatakan jika tinggi rendahnya hutang perusahaan tidak memengaruhi pembayaran dividen kepada para pemegang saham. Selain itu, berdasarkan hasil pengujian yang telah dilakukan juga dapat diketahui jika return on asset berpengaruh secara langsung terhadap kebijakan dividen. Melalui hasil tersebut maka, semakin positif nilai return on asset (ROA) maka pengelolaan perusahaan lebih efisien yang nantinya akan menjadikan perusahaan menghasilkan laba yang lebih tinggi. Hasil penelitian ini juga menunjukkan bahwa earning per share memiliki pengaruh secara langsung terhadap kebijakan dividen. Melalui hasil tersebut maka dapat menjelaskan bahwa earning per share (EPS) memperlihatkan rasio bagi hasil dari setiap saham yang dimiliki. Semakin meningkatnya earning per share maka akan semakin menyenangkan bagi para pemegang saham.

Hasil pengujian yang telah dilakukan juga mengungkapkan bahwa debt to equity ratio tidak memiliki pengaruh secara langsung terhadap harga saham. Oleh karena itu, dapat dikatakan jika tinggi rendahnya nilai debt to equity ratio (DER) tidak memengaruhi seorang investor dalam membeli sebuah saham. Seorang investor cenderung lebih sering mengamati 
trend di pasar saham. Akan tetapi, mereka hanya menginginkan laba jangka pendek yang berupa capital gain. Hal tersebutlah yang menjadikan debt to equity ratio (DER) tidak berpengaruh terhadap harga saham. Melalui hasil pengujian yang telah dilakukan pula diketahui jika return on asset berpengaruh secara langsung terhadap harga saham. Oleh sebab itu, semakin tinggi nilai return on asset (ROA) maka perusahaan akan menghasilkan laba yang lebih besar pula dari aset yang dimilikinya. Hasil pengujian yang telah dilakukan juga mengungkapkan bahwa earning per share memiliki pengaruh secara langsung terhadap harga saham. Semakin tinggi earning per share maka akan menjadikan seorang investor lebih tertarik. Hal tersebut dikarenakan earning per share (EPS) menandakan meskipun harga saham mengalami kenaikan, akan tetapi keuntungan yang diterima investor juga akan meningkat.

Berdasarkan hasil pengujian yang telah dilakukan kebijakan dividen tidak memiliki pengaruh secara langsung terhadap harga saham. Dengan demikian, dapat dikatakan jika jumlah pembagian dividen terhadap para pemegang saham tidak memengaruhi naik dan juga turunnya harga saham. Selain itu, penelitian ini juga memiliki hasil jika kebijakan dividen tidak memediasi pengaruh debt to equity ratio terhadap harga saham. Berdasarkan hasil itu pula dapat dikatakan bahwa meningkatnya harga saham tidak melihat nilai debt to equity ratio melalui kebijakan dividen. Hal tersebut dikarenakan meningkatnya nilai debt to equity ratio tidak dapat menjadikan dividen yang diterima para pemegang saham juga akan meningkat.

Melalui hasil pengujian yang telah dilakukan return on asset tidak memiliki pengaruh tidak langsung terhadap harga saham melalui kebijakan dividen. Hal tersebut dapat dikatakan jika laba yang diperoleh perusahaan dari aset yang dimiliki tidak semua dialokasikan ke dalam bentuk dividen untuk dibagikan kepada para pemegang saham perusahaan. Selain itu, jika perusahaan yang dapat memperoleh laba yang tinggi belum tentu membuat tanggapan investor terhadap perusahaan baik pula dan hal tersebut juga belum tentu berdampak pada naiknya harga saham. Adapun kelemahan dalam penelitian ini adalah dalam penentuan variabel eksogen penelitian tidak memperhatikan faktor-faktor apa saja yang dapat memengaruhi harga saham maupun kebijakan dividen. Oleh karena itu, masih terdapat hasil yang penelitian yang menunjukkan tidak adanya pengaruh terhadap harga saham dan juga kebijakan dividen.

\section{Saran}

Bagi peneliti selanjutnya, dapat menambah periode yang digunakan dalam penelitian serta tidak terbatas hanya pada perusahaan sektor industri barang konsumsi saja. Selain itu, peneliti selanjutnya juga diharapkan dapat menambahkan jumlah variabel dalam penelitian yang dapat memengaruhi kebijakan dividen dan juga harga saham. 


\section{DAFTAR PUSTAKA}

Alifah, N., \& Diyani, L.A. (2017). Pengaruh ROE dan DER Terhadap Harga Saham pada Sektor Perdagangan Eceran. Jurnal Bisnis Terapan, 1(2), 47-54.

Aprilia, I. (2017, Desember 24). 56 Persen Pertumbuhan Ekonomi Indonesia Disumbang oleh Konsumsi. Kompas. Diakses dari www.kompas.com/ekonomi/read/2017/12/24/165533626/56-persen-pertumbuhanekonomi-indonesia-disumbang-oleh-konsumsi

Aprillianto, B., Wulandari, N., \& Kurrohman, T. (2014). Perilaku Investor Saham Individual Dalam Pengambilan Keputusan Investasi: Studi Hermeneutika-Kritis. e-Journal Ekonomi Bisnis dan Akuntansi, 1(1), 16-31.

Arif, D. (2019). Pengaruh Profitabilitas, Leverage, Growth Terhadap Harga Saham Melalui Kebijakan Dividen Sebagai Variabel Intervening. [Skripsi]. Jakarta: Program Studi Manajemen Fakultas Ekonomi dan Bisnis, Universitas Islam Negeri Syarif Hidayatullah. Diakses dari http://repository.uinjkt.ac.id/dspace/bitstream/123456789/49968/1/DENNY\%20ARIF -FEB.pdf

Ariyani, L., Andini, R., \& Santoso, E.B. (2018). Pengaruh EPS, CR, DER, dan PBV Terhadap Harga Saham dengan Kebijakan Dividen Sebagai Variabel Intervening (Studi pada Perusahaan Manufaktur yang Terdaftar di BEI tahun 2011-2015). Jurnal Ilmiah Mahasiswa S1 Akuntansi Universitas Pandanaran, 4(4), 1-20.

Bangun, N., \& Hardiman, S. (2012). Analisis Pengaruh Profitabilitas, Cash Position, Debt to Equity Ratio (DER), dan Kesempatan Investasi terhadap Kebijakan Dividen pada Perusahaan Manufaktur yang Terdaftar di Bursa Efek Indonesia (BEI) pada tahun 2008-2010. Jurnal Pasar Modal dan Perbankan, 1(2), 80-102.

Brigham, E.F., \& Houston, J.F. (2010). Dasar-Dasar Manajemen Keuangan. Jakarta: Salemba Empat.

Bulutoding, L., Parmitasari, R.D., \& Dahlan, M. A. (2018). Pengaruh Return on Asset (ROA) dan Debt to Equity Ratio (DER) Terhadap Harga Saham dengan Kebijakan Dividen Sebagai Variabel Intervening. Jurnal Ilmiah Akuntansi Peradaban, IV(2), 1-14.

Cahyaningrum, Y.W., \& Antikasari, T.W. (2017). Pengaruh Earning Per Share, Price To Book Value, Return On Asset, dan Return On Equity Terhadap Harga Saham Sektor Keuangan. Jurnal Economia, 13(2), 191-200.

Clarensia, J.R., \& Azizah, N. (2013). Pengaruh Likuiditas, Profitabilitas, Pertumbuhan Penjualan, dan Kebijakan Dividen Terhadap Harga Saham. Jurnal Ilmiah Universitas Budi Luhur, 1(1), 72-88.

Darmadji, T., \& Fakhruddin. (2012). Pasar Modal di Indonesia. Edisi Ketiga. Jakarta: Salemba Empat.

Darsono, \& Ashari. (2005). Pedoman Praktis Memahami Laporan Keuangan. Yogyakarrta: Universitas Diponegoro.

Deitiana, T. (2009). Pengaruh Rasio Keuangan dan Pertumbuhan Penjualan Terhadap Dividen dan Implikasinya Pada Harga Saham. Jurnal Akuntansi, XVI(02), 191-208. 
Deitiana, T. (2011). Pengaruh Rasio Keuangan, Pertumbuhan Penjualan, dan Dividend Terhadap Harga Saham. Jurnal Bisnis dan Akuntansi, 1(1), 57-66.

Devi, I.N., \& T., S. (2015). Pengaruh PBV, EPS, dan DER Terhadap Harga Saham dengan Kebijakan Dividen Sebagai Variabel Intervening: Studi pada Perusahaan Manufaktur yang terdaftar di BEI tahun 2009-2013. Jurnal Ilmiah Mahasiswa Fakultas Ekonomi dan Bisnis. 4(1), 1-21.

Dewi, P.D., \& Suaryana, I. (2013). Pengaruh EPS, DER, dan PBV Terhadap Harga Saham. Jurnal Akuntansi, 4(1), 215-229.

Dianti, O., \& Badjra, I.B. (2016). Pengaruh Earning Per Share, Tingkat Pertumbuhan Perusahaan dan Current Ratio Terhadap Kebijakan Dividen. E-Jurnal Manajemen Unud, 5(11), 6795-6824.

Difah, S.S. (2011). Analisis Faktor-Faktor yang Mempengaruhi Dividend Payout Ratio Pada Perusahaan BUMN yang Terdaftar di Bursa Efek Indonesia Periode Tahun 20042009. [Skripsi]. Semarang: Fakultas Ekonomi Universitas Diponegoro. Diakses dari http://eprints.undip.ac.id/27438/1/Skripsi_Difah(r).pdf

Ghozali, I. (2017). Analisis Multivariat dan Ekonometrika dengan Eviews 10. Semarang: Badan Penerbit Universitas Diponegoro.

Gohar, R., \& Alam, M.S. (2018). Determinants and Behavior of Dividend Policy in Pakistani Listed Companies. Journal of Finance and Investment Analysis, 7(3), 1-9.

Hanum, Z. (2009). Pengaruh Return On Asset (ROA), Return On Equity (ROE), dan Earning Per Share (EPS) Terhadap Harga Saham pada Perusahaan Otomotif yang Terdaftar di BEI periode 2008-2011. Jurnal Manajemen dan Bisnis, 8(2).

Haque, M.R., Datta, R.K., Dey, R., \& Rahman, M. (2013). Financial Variables Having Significant Impact on Market Price of Share. Research Journal of Finance and Accounting, 4(15), 76-80.

Herawati, A., \& Putra, A.S. (2018). The Influence of Fundamental Analysis on Stock Prices: The Case of Food and Beverage Industries. Management and Entrepreneurship Journal, XXI(3), 316-326.

Hermuningsih, S. (2012). Pengantar Pasar Modal Indonesia. Yogyakarta: UPP STIM YKPN.

Horne, J.C., \& John, M.W. (2009). Prinsip-Prinsip Manajemen Keuangan. Jakarta: Salemba Empat.

Hutami, R.P. (2012). Pengaruh Dividend Per Share, Return On Equity, dan Net Profit Margin Terhadap Harga Saham Perusahaam Industri Manufaktur yang tercatat di Bursa Efek Indonesia periode 2006-2010. Jurnal Nominal, 1(1), 104-123.

Janifairus, J.B., Hidayat, R., \& Husaini, A. (2013). Pengaruh Return On Asset, Debt to Equity Ratio, Assets Growth, dan Cash Ratio Terhadap Dividen Payout Ratio. Jurnal Administrasi Bisnis, 1(1), 161-169.

Jogiyanto. (2012). Teori Portofolio dan Analisis Investasi: Edisi Ketujuh. Yogyakarta: BPFE Yogyakarta. 
Kartika, A.V., Topowijono, \& Endang, M.W. (2015). Pengaruh Return On Asset, Return On Equity dan Asset Growth Terhadap Dividend Payout Ratio (Studi pada Perusahaan Manufaktur yang Terdaftar di Bursa Efek Indonesia Periode 2010-2012). Jurnal Administrasi Bisnis, 1(2), 1-11.

Kartikasari, U. (2019). Pengaruh Debt To Equity Ratio, Current Ratio, dan Return On Asset Terhadap Harga Saham Perusahaan Infrastruktur Terdaftar di Bursa Efek Indonesia Periode 2008-2017. Management and Entrepreneurship Journal, II(1), 41-50.

Lestari, A.P., \& Susetyo, A. (2020). Pengaruh NPM, EPS, DER dan PBV Terhadap Harga Saham pada Perusahaan Terdaftar IDX HIDIV20 Dengan DPR Sebagai Variabel Intervening. Jurnal Ilmiah Manajemen, Bisnis dan Akuntansi, 2(2), 184-196.

Lisna, D., \& Sudiartha, G.M. (2011). Pengaruh Cash Ratio, Debt to Equity Ratio, dan Earning Per Share Terhadap Cash Dividend Pada Perusahaan Food and Beverages yang Terdaftar di Bursa Efek Indonesia Periode 2005-2010. Jurnal Fakultas Ekonomi, 217-232.

Masry, M., Sakr, A., \& Amer, M. (2018). Factors Affecting Dividend Policy in an Emerging Capital Markets (ECM's) Country: Theoratical and Empirical Study. International Journal of Economics, Finance and Management Sciences, 6(4), 139-152.

Mehta, A. (2012). An Empirical Analysis of Determinants of Dividend Policy - Evidence from The UAE Companies. Global Reviews of Accounting and Finance, 3(1), 18-31.

Muniarti, S. (2016). Effect of Capital Structure, Company Size and Profitability on the Stock Price of Food and Beverage Companies Listed on the Indonesia Stock Exchange. Information Management and Business Review, 8(1), 23-29.

Noviana. (2012). Pengaruh EPS, CFOPS, CR, dan Growth terhadap Dividend Payout Ratio pada Perusahaan Manufaktur yang Terdaftar di Bursa Efek Indonesia 2008-2011. Jurnal Manajemen.

Oktadella, D. (2011). Analisis Corporate Governance Terhadap Integritas Laporan Keuangan. 1-31. Diakses dari http://eprints.undip.ac.id/28639/1/JURNAL.pdf

Puspita, E. (2017). Pengaruh Likuiditas, Profitabilitas, Leverage, dan Market Ratio Terhadap Dividend Payout Ratio Pada Perusahaan Manufaktur. Jurnal Bidang Ilmu Ekonomi, 12(1), 17-35.

Rahmadewi, P. W., \& Abundanti, N. (2018). Pengaruh EPS, PER, CR dan ROE Terhadap Harga Saham di Bursa Efek Indonesia. E-Journal Manajemen Unud, 7(4), 21062133.

Rahmawati, D., \& Suryono, B. (2017). Pengaruh DPR, EPS, dan DER Terhadap Harga Saham. Jurnal Ilmu dan Riset Akuntansi, 6(6), 1-17.

Sari, A. N. (2017). Pengaruh Profitabilitas, Kebijakan Dividen, Struktur Modal dan Ukuran Perusahaan Terhadap Nilai Perusahaan (Studi Empiris Pada Perusahaan Manufaktur Sektor Industri Barang Konsumsi yang Terdaftar di Bursa Efek Indonesia Periode 2013-2015). 1-9.

Satryo, A. G., Rokhmania, N. A., \& Diptyana, P. (2016). The Influence of Profitability Ratio, Market Ratio, and Solvency Ratio on The Share Price of Companies Listed LQ45 Index. The Indonesian Accounting Review, 6(1), 55-66. 
Sha, T. L. (2015). Pengaruh Kebijakan Dividen, Likuiditas, Net Profit Margin, Return On Equity, dan Price To Book Value Terhadap Harga Saham Pada Perusahaan Manufaktur yang Terdaftar di Bursa Efek Indonesia 2010-2013. Jurnal Akuntansi, XIX(02), 276-294.

Siswantini, W. (2014). Pengaruh Analisis Rasio Keuangan Terhadap Kebijakan Dividen (Studi Empiris pada Perusahaan Real Estate dan Property yang terdaftar di Bursa Efek Indonesia). Jurnal Organisasi Manajemen, 10(2), 136-147.

Sitorus, J. S., Funny, Marcella, C., Evelyn, \& Gunawan, J. (2020). Pengaruh CR (Current Ratio), DER (Debt to Equity Ratio), EPS (Earning Per Share) dan Financial Distreass (Altman Score) Terhadap Harga Saham Pada Perusahaan Sektor Industri Dasar dan Kimia yang Terdaftar di Bursa Efek Indonesia. Riset \& Jurnal Akuntansi, 4(1), 1-15.

Sugiarto, R. J. (2014). Pengaruh DER, ROA, Terhadap Harga Saham pada Perusahaan Telekomunikasi di BEI. Jurnal Ilmu \& Riset Manajemen, 3(9).

Sugiyono. (2010). Metode Penelitian Kuantitatif Kualitatif \& RND. Bandung: Alfabeta.

Suharli, M. (2006). Studi Empiris Mengenai Pengaruh Profitabilitas, Leverage, dan Harga Saham Terhadap Jumlah Dividen Tunai (Studi pada Perusahaan yang Terdaftar di Bursa Efek Jakarta Periode 2002-2003). Jurnal Maksi, 6(2), 243-256.

Suryawan, I. G., \& Wirajaya, I. A. (2017). Pengaruh Current Ratio, Debt to Equity Ratio dan Return On Asset pada Harga Saham. E-Jurnal Akuntansi Universitas Udayana, 21(2), 1317-1345.

Sutrisno. (2003). Manajemen Keuangan. Teori Konsep dan Aplikasi. Edisi Pertama. Yogyakarta: EKONSIA.

Thim, C. K., Choong, Y. V., \& Asri, N. Q. (2012). Stock Performance of the Property Sector in Malaysia. Journal of Modern Accounting and Auditing, 8(2), 241-246.

Yudhanto. (2013). Pengaruh Net Profit Margin, Return On Asset, Return On Equity, Earning Per Share Terhadap Kebijakan Dividen (Studi pada Perusahaan Manufaktur yang Terdaftar di Bursa Efek Indonesia). 1-13.

Yudhanto, S. (2012). Pengaruh Net Profit Margin, Return On Asset, Return On Equity, Earning Per Share Terhadap Kebijakan Dividen. Jurnal Ekonomi dan Binis, 1(2).

Zuliarni, S. (2012). Pengaruh Kinerja Keuangan Terhadap Harga Saham Pada Perusahaan Mining and Mining Service di Bursa Efek Indonesia (BEI). Jurnal Aplikasi Bisnis, 36-48. 